\author{
RAFAŁ MIKOWSKI \\ ORCID: 0000-0002-9465-8510 \\ Uniwersytet Wrocławski \\ Instytut Nauk Administracyjnych \\ Zakład Prawa Administracyjnego
}

\title{
ODPOWIEDZIALNOŚĆ PODMIOTÓW ADMINISTRUJĄCYCH ZA MARTWĄ ZWIERZYNĘ
}

\begin{abstract}
Abstrakt: W opracowaniu wskazane zostały podmioty administrujące właściwe w zakresie usuwania martwych zwierząt, ze szczególnym uwzględnieniem działań dotyczących bezpańskich zwierząt oraz zwierzyny dzikiej. Uwzględnione zostały zarówno przepisy dotyczące samej procedury, jak i pozycji ustrojowej właściwych organów oraz zadań i kompetencji na płaszczyźnie administracyjnoprawnej. Szczególnie istotne problemy przeanalizowane zostały w świetle przepisów regulujących prawo własności do rzeczy ruchomych i w stosunku do zdarzeń mających miejsce na terenach nieruchomości prywatnych. W rozważaniach uwzględniono analizę przypadków związanych z obowiązkiem usunięcia martwej, dzikiej zwierzyny z terenu nieruchomości prywatnej.
\end{abstract}

Słowa kluczowe: ochrona zwierząt, martwe zwierzęta, utrzymanie porządku i czystości, utylizacja zwłok zwierzęcych

\section{WPROWADZENIE}

W życiu człowieka szczególne miejsce zajmują zwierzęta — zarówno te, które hodowane są w celach konsumpcyjnych, jak i te, które towarzyszą człowiekowi na co dzień, zaspokajając jego potrzeby bytowe, skupione wokół walorów estetycznych oraz potrzeb duchowych ${ }^{1}$. Bezsprzecznym faktem stała się dzisiaj troska o byt wszelakich zwierząt, wyrażona w regulacjach prawnych dotyczących zapewnienia im godnych warunków życia — związanych z koegzystowaniem we wspólnym, najbliższym otoczeniu, a także w szeroko rozumianym środowisku przyrodniczym² ${ }^{2}$.

1 Zob. między innymi: C. Janik, Status zwierzęcia w głównych systemach religijnych, [w:] Status zwierzęcia. Zagadnienia filozoficzne i prawne, red. T. Gardocka, A. Gruszczyńska, Toruń 2012; T. Kaleta, Zwierzęta we współczesnych religiach światowych. Wybrane zagadnienia, „Życie Weterynaryjne" 2011, nr 86 (9).

2 Zwierzęta postrzegane są zarówno jako element przyrody, jak i element samego środowiska, na co wskazuje użycie w art. 3 pkt 39 ustawy z dnia 27 kwietnia 2001 roku Prawo ochrony środo- 
O ile nie ma większych problemów z ustaleniem momentu, w którym rozpoczynają się obowiązki poszczególnych podmiotów w zakresie ochrony bytu zwierzęcia, o tyle problematyczne staje się ustalenie podmiotu odpowiedzialnego za los martwego zwierzęcia. Liczne dyskursy na temat prawnych i filozoficznych aspektów ochrony zwierząt ${ }^{3}$ oraz analiza regulacji prawnych w tym zakresie nie dają jednoznacznej odpowiedzi na pytanie, kto jest odpowiedzialny za los zwierząt martwych. Wydaje się w tym miejscu konieczne prześledzenie regulacji prawnych i osiągnięć doktryny w odniesieniu do praktyki podmiotów administrujących odpowiedzialnych za losy zwierząt i ich analiza w kontekście praw i obowiązków właściciela nieruchomości, na której może znaleźć się martwe zwierzę. Można wskazywać na obowiązki poszczególnych podmiotów w zakresie utrzymania czystości w gminach, podmiotów odpowiedzialnych za utrzymanie odpowiednich warunków bytowych zwierząt, w tym także zdrowotnych, podmiotów odpowiedzialnych za utrzymanie dróg publicznych, ale zauważyć należy również obowiązki osób fizycznych w relacji do uprawnień wynikających z prawa własności danej nieruchomości czy prawa własności rzeczy ruchomych, które mają zastosowanie do zwierząt.

Potrzeba ochrony zwierząt wynika nie tylko ze świadomości człowieka jako gatunku odpowiedzialnego za podporządkowywanie sobie wszystkich elementów przyrody, ale także z uznania zwierzęcia za organizm zdolny do odczuwania ${ }^{4}$ bólu, cierpienia i emocji ${ }^{5}$. Znajduje to wyraz w obowiązujących regulacjach, wśród których szczególną rolę odgrywa art. 1 ustawy z dnia 21 sierpnia 1997 roku o ochronie zwierząt $^{6}$. Ustawodawca jednoznacznie stwierdza, że zwierzę, jako istota żyjąca, zdolna do odczuwania cierpienia, nie jest rzeczą. W związku z tym człowiek jest winien zwierzęciu poszanowanie, ochronę i opiekę. Ale czy wszystkie te przymioty i walory przypisywane zwierzęciu i związane z nimi ludzkie odczucia zachowują swoją aktualność po śmierci zwierzęcia? Czy w tym szczególnym momencie nie zostają przyćmione przez zapis zawarty w art. 1 ust. 2 komentowanej ustawy, w którym czytamy, że w sprawach nieuregulowanych w ustawie do zwierząt stosuje się odpowiednio przepisy dotyczące rzeczy? Czy nie jest tak, że po śmierci

wiska (Dz.U. z 2019 r. poz. 1396 ze zm.) pojęcia elementów różnorodności przyrodniczej — zob. B. Rakoczy, Prawo ochrony przyrody, Warszawa 2009, s. 98.

3 Zob. D. Probucka, Filozoficzne podstawy idei praw zwierząt, Kraków 2013; R. Węgrzynowicz, M. Romańska, Ochrona zwierząt w świetle prawa i norm etycznych, [w:] Prawna ochrona zwierzat, red. M. Mozgawa, Lublin 2002.

${ }^{4}$ W literaturze można bez problemu odnaleźć pogląd, że między ludźmi a zwierzętami nie ma większej różnicy w sposobie odczuwania takich bodźców, jak ból, strach czy emocje — zob. M. Mitera, Kilka uwag o prawach zwierząt, [w:] Przełomy wieków, red. M. Szyszkowska, Białystok 2000, s. 107.

5 Tak postrzegana ochrona zwierząt, nazywana ochroną humanitarną, prawidłowo powinna być motywowana względami pozagospodarczymi — zob. M. Górski, J. Miłkowska-Rębowska, Komentarz do art. 13 Traktatu o funkcjonowaniu Unii Europejskiej, [w:] Traktat o funkcjonowaniu Unii Europejskiej. Komentarz, t. I (art. 1-89), red. D. Miąsik et al., Lex 2012.

${ }^{6}$ Dz.U. z 2019 r. poz. 122 z późn. zm. 
zwierzęcia mamy do czynienia już tylko z rzeczą ${ }^{7}$ - i to najczęściej z rzeczą niechcianą, stwarzającą problem moralny, prawny i finansowy?

\section{ODPOWIEDZIALNOŚĆ GMINY}

Przyjęty w ustawodawstwie polskim model samorządu terytorialnego jednoznacznie wskazuje na dualistyczny charakter wykonywania zadań przez jednostki samorządu terytorialnego ${ }^{8}$. Gmina wykonuje zarówno zadania własne, jak i zadania zlecone z zakresu administracji rządowej. Zgodnie z art. 6 ustawy z dnia 8 marca 1990 roku o samorządzie gminnym ${ }^{9} \mathrm{w}$ zakres działania gminy wchodzą wszystkie sprawy publiczne ${ }^{10}$ o znaczeniu lokalnym, które nie zostały zastrzeżone ustawami na rzecz innych podmiotów. Ustawodawca wskazał w art. 7 ust. 1 komentowanej ustawy na zaspokajanie zbiorowych potrzeb wspólnoty, które określił jako zadanie własne gminy, przy czym należy zauważyć, że z konstrukcji tego przepisu wynika, iż nie jest to katalog zamknięty. Potwierdzone to zostało w art. 7 ust. 3 analizowanej ustawy, w którym ustawodawca przewidział przekazanie gminie, w drodze ustawy, nowych zadań własnych. Zgodnie z art. 7 ust. 2 wśród zadań własnych gminy można wyróżnić te, które gmina musi realizować obowiązkowo ${ }^{11}$. Na zadania te wskazują: ustawa z dnia 25 października 1991 roku o organizowaniu i prowadzeniu działalności kulturalnej ${ }^{12}$, ustawa z dnia 13 września 1996 roku o utrzymaniu czystości i porządku w gminach ${ }^{13}$, ustawa $\mathrm{z}$ dnia 12 marca 2004 roku o pomocy społecznej ${ }^{14}$ i ustawa z dnia 7 września 1991 roku o systemie oświaty ${ }^{15}$.

Analizując przepisy ustawy o utrzymaniu czystości i porządku w gminach, można jednoznacznie stwierdzić, że wśród licznych zadań własnych gminy akcentowane są także te związane z postępowaniem z martwą zwierzyną ${ }^{16}$. Zgodnie

${ }^{7}$ Czy intelektualne osiągnięcie związane z normatywną dereifikacją zwierząt aktualne pozostaje także po śmierci zwierzęcia?

8 J. Jendrośka, Modele samorządu terytorialnego, [w:] Prawo administracyjne, red. J. Boć, Wrocław 2010, s. 187.

9 Dz.U. z 2019 r. poz. 506 z późn. zm.

10 Szerzej: Zadania $i$ kompetencje jednostek samorzadu terytorialnego $i$ wojewody, red. Z. Bukowski et al., Torun 2004.

11 Gmina nie może odmówić realizacji tego typu zadań, ponieważ ich obligatoryjny charakter wynika z norm prawa materialnego - K. Nowacki, W Austrii, [w:] Gmina w Europie Zachodniej, red. J. Jeżewski, Wrocław 1995.

12 Dz.U. z 2020 r. poz. 194 z późn. zm.

13 Dz.U. z 2019 r. poz. 2010 z późn. zm.

14 Dz.U. z 2019 r. poz. 1507 z późn. zm.

15 Dz.U. z 2019 r. poz. 1481 z późn. zm.

16 Charakteru własnego tego typu zadań należy upatrywać w przyczynie ich powstawania, która pojmowana jest tutaj zarówno podmiotowo, jak i przestrzennie przedmiotowo, na co wskazują 
$\mathrm{z}$ art. 3 ust. 2 pkt 2 lit. c) komentowanej ustawy odbywa się to poprzez zapewnienie budowy, utrzymania i eksploatacji instalacji i urządzeń do zbierania, transportu i unieszkodliwiania zwłok zwierzęcych lub ich części. Z konstrukcji art. 3 ust. 2 pkt 15 analizowanej ustawy wnioskować można, że ustawodawca ograniczył przedmiotowe obowiązki wyłącznie do zwierząt bezdomnych. Zgodnie z art. 4 pkt 16 ustawy o ochronie zwierząt przez zwierzęta bezdomne rozumieć należy zwierzęta domowe ${ }^{17}$ lub gospodarskie ${ }^{18}$, które uciekły, zabłąkały się lub zostały porzucone przez człowieka, a nie ma możliwości ustalenia ich właściciela lub innej osoby, pod której opieką trwale dotąd pozostawały. Jednoznaczne wskazanie w komentowanym przepisie na zwierzęta domowe i gospodarskie wyklucza z pojęcia bezdomności zwierzęta dziko występujące w przyrodzie, co oznacza, że nie powinno być w takim przypadku trudności z ustaleniem prawa do władania tą kategorią zwierzyny. Co prawda art. 3 ust. 2 ustawy o utrzymaniu czystości i porządku w gminach nie formułuje zamkniętego katalogu obowiązków gminy ${ }^{19} \mathrm{w}$ przedmiotowym zakresie, nie wydaje się jednak uprawniony pogląd, że można niejako automatycznie rozciągnąc wpisanie obowiązku usunięcia martwej dzikiej zwierzyny w katalog zadań gminy $^{20}$. Nie potwierdza tego także analiza art. 7 ustawy o samorządzie gminnym, w którym wskazano jako zadanie własne gminy zaspokajanie zbiorowych potrzeb wspólnoty, a w szczególności sprawy dotyczące ładu przestrzennego, gospodarki nieruchomościami, ochrony środowiska i przyrody oraz gospodarki wodnej ${ }^{21}$. Można tutaj przyjąć, że ustawodawca chce zaakcentować ogólną zasadę ,zanieczyszczający płaci”22, którą w tym przypadku zidentyfikować można by było poprzez rozciągnięcie jej ogólnego brzmienia na obowiązek usunięcia padłego zwierzęcia przez podmiot, na którego terenie zdarzenie takie miało miejsce.

działania wspólnoty samorządowej, wykonywane tak we własnym, jak w ogólnospołecznym interesie - M. Górski, Prawo ochrony środowiska, Warszawa 2009, s. 87.

17 Zwierzęta domowe to zwierzęta tradycyjnie przebywające wraz z człowiekiem w jego domu lub innym odpowiednim pomieszczeniu, utrzymywane przez człowieka w charakterze jego towarzysza - zob. art. 4 pkt 17 ustawy o ochronie zwierząt.

18 Zwierzęta gospodarskie to zwierzęta gospodarskie w rozumieniu przepisów o organizacji hodowli i rozrodzie zwierząt gospodarskich — zob. art. 4 pkt 18 ustawy o ochronie zwierząt. Definicja zwierząt gospodarskich została zamieszczona w art. 2 pkt 1 ustawy z dnia 29 czerwca 2007 roku o organizacji hodowli i rozrodzie zwierząt gospodarskich (Dz.U. z 2017 r. poz. 2132). Ustawodawca wskazuje w tej kategorii na zwierzęta koniowate, bydło, jeleniowate, drób, świnie, owce, kozy, pszczołę miodną, zwierzęta futerkowe.

19 Należy pamiętać także, że gmina w drodze uchwały kreuje i doprecyzowuje przedmiotowe obowiązki w regulaminie utrzymania czystości i porządku, który opiniowany jest przez powiatowego inspektora sanitarnego - zob. W. Radecki, Utrzymanie czystości i porządku w gminach. Komentarz, Warszawa 2012, s. 142.

20 Nie jest w tym miejscu właściwe także twierdzenie, że obowiązek taki można wyprowadzić z ogólnej kompetencji gminy do zapewnienia czystości i porządku w jej granicach administracyjnych — zob. Z. Rydzicki, J. Sybiga, Utrzymanie porzadku i czystośsi w gminach, Warszawa 1997.

21 Por. T. Bartkowski, Ksztaltowanie i ochrona środowiska, Warszawa 1979, s. 47.

22 Zasada ta zdefiniowana została między innymi w art. 7 ustawy Prawo ochrony środowiska. 


\section{ODPOWIEDZIALNOŚĆ ZARZĄDCY DROGI}

Z problemem martwej zwierzyny możemy mieć do czynienia na terenach gminnych, w tym drogach, których właścicielem jest gmina, a także na drogach publicznych ${ }^{23}$, przebiegających co prawda w administracyjnych granicach gminy, jednak nienależących do gminy. Tutaj sytuacja komplikuje się jeszcze bardziej, ponieważ analizowany obowiązek obciąża nie tylko zarządzającego drogą, ale pośrednio dotyczy także uczestników ruchu drogowego, w tym służb odpowiedzialnych za zagwarantowanie bezpieczeństwa na drogach publicznych ${ }^{24}$. Obowiązki utrzymania czystości i porządku na drogach publicznych jednoznacznie wyartykułowane zostały w art. 5 ust. 4 ustawy o utrzymaniu czystości i porządku w gminach przez wskazanie na zarządcę drogi jako podmiot odpowiedzialny za ich realizację. W świetle tej regulacji do obowiązków zarządcy drogi należy także zbieranie i pozbywanie się odpadów zgromadzonych w pojemnikach lub workach do tego przeznaczonych i utrzymanie tych pojemników w odpowiednim stanie sanitarnym, porządkowym i technicznym oraz utrzymanie $\mathrm{w}$ odpowiednim stanie sanitarnym i porządkowym miejsc gromadzenia odpadów. Kolejno wskazany został obowiązek pozbywania się błota, śniegu, lodu i innych zanieczyszczeń uprzątniętych z chodników przez właścicieli nieruchomości przyległych do drogi publicznej. W końcu na zarządcy drogi ciąży także obowiązek uprzątnięcia i pozbycia się błota, śniegu, lodu i innych zanieczyszczeń z chodników, jeżeli zarząd drogi pobiera opłaty z tytułu postoju lub parkowania pojazdów samochodowych na takim chodniku. Mimo że ustawodawca nie wskazuje w tym miejscu jednoznacznie, kto jest zobowiązany do podjęcia działań związanych z usunięciem martwej zwierzyny z drogi publicznej, właściwe wydaje się rozszerzenie omawianego zakresu także na zwłoki zwierzyny. Wspólnym mianownikiem wymienionych w komentowanym przepisie przypadków jest niewątpliwie usunięcie zanieczyszczenia $^{25}$ czy w wielu przypadkach przeszkody leżącej na drodze publicznej, jaką w ta-

23 Zgodnie z art. 1 ustawy z dnia 21 marca 1985 roku o drogach publicznych (Dz.U. z 2018 r. poz. 2068 z późn. zm.) drogą publiczną jest droga zaliczona na podstawie ustawy do jednej z kategorii dróg, z której może korzystać każdy, zgodnie z jej przeznaczeniem, z ograniczeniami i wyjątkami określonymi w tej ustawie lub innych przepisach szczególnych — zob. między innymi: W. Maciejko, P. Zaborniak, Ustawa o drogach publicznych. Komentarz, Warszawa 2010; R. Rychter, Ustawa o drogach publicznych. Komentarz, wyd. 2, Lex 2019.

${ }^{24}$ Można zaryzykować w tym miejscu stwierdzenie, że przedmiotowy obowiązek wynika nie tylko stricte z norm prawnych, ale także ze wspólnych wartości wszystkich korzystających z drogi publicznej, postrzeganych jako wartości życia społecznego, które mają sens tylko w przypadku wspólnego ich realizowania - por. J. Gałkowski, Zasada proporcjonalności, „Więź” 1983, z. 1, s. 65.

25 Rozczłonkowane (najczęściej w wyniku zdarzenia drogowego) zwłoki zwierzyny stanowią także zanieczyszczenie drogi, które stanowi zagrożenie nie tylko ze względu na bezpieczeństwo ruchu drogowego, ale także ze względu na bezpieczeństwo sanitarne i epidemiologiczne. Jak pisze J. Boć, ,z walorem bezpieczeństwa zostały zrównane takie wartości, jak porządek publiczny, ochrona środowiska, zdrowie i moralność publiczna" — J. Boć, O bezpieczeństwie wewnętrznym, [w:] Bezpieczeństwo wewnętrzne w działaniach terenowej administracji publicznej, red. A. Chajbowicz, T. Kocowski, Wrocław 2009, s. 20. 
kim wypadku jest martwe zwierzę. Zarządca drogi powinien podejmować szereg różnych działań, nie tylko wskazanych w analizowanym przepisie, które mają na celu zapewnienie porządku na drodze, a tym samym zagwarantowanie innym uczestnikom ruchu drogowego bezpieczeństwa. Potwierdzenie takiego wnioskowania można znaleźć w ustawie z dnia 21 marca 1985 roku o drogach publicznych ${ }^{26}$, której art. 20 pkt 4 do podstawowych obowiązków zarządcy drogi zalicza utrzymanie nawierzchni drogi, chodników, drogowych obiektów inżynierskich, urządzeń zabezpieczających ruch $\mathrm{i}$ innych urządzeń związanych z drogą, co w związku z pkt 10 komentowanego artykułu doprecyzowuje obowiązek podejmowania działań ze szczególnym uwzględnieniem ich wpływu na stan bezpieczeństwa ruchu drogowego, w tym weryfikację cech i wskazanie usterek, które wymagają prac konserwacyjnych lub naprawczych ze względu na bezpieczeństwo ruchu drogowego.

Usunięcie martwej zwierzyny z drogi publicznej należy rozpatrywać w kategoriach czynności podejmowanych $\mathrm{w}$ celu zapewnienia bezpieczeństwa ruchu drogowego, co wzmocnione zostało przez regulacje zawarte $\mathrm{w}$ ustawie $\mathrm{z}$ dnia 20 czerwca 1997 roku Prawo o ruchu drogowym ${ }^{27}$, która nakłada obowiązek dbałości o bezpieczeństwo na drogach na wszystkich użytkowników ruchu drogowe$\mathrm{go}^{28}$. W tym miejscu zaznaczyć należy, że obowiązek zachowania bezpieczeństwa i porządku na drogach publicznych ${ }^{29}$ ciąży na wszystkich uczestnikach ruchu drogowego, nad czym czuwać mają także właściwe służby z policją na czele. Tak więc wydaje się, że w sytuacji, kiedy na drodze pozostaje martwe zwierzę, zarówno uczestnicy ruchu drogowego, jak i służby odpowiedzialne za zagwarantowanie bezpieczeństwa i porządku na drogach mają obowiązek podjąć właściwe działania zmierzające do usunięcia zagrożenia $\mathrm{z}$ drogi. Nie wydaje się jednak, by takie normatywne i zwyczajowe podejście do przedmiotowego problemu zmuszało uczestników ruchu drogowego do podjęcia bezpośrednich działań zmierzających do fizycznego usunięcia zwłok zwierzęcia z drogi. Właściwsze wydaje się zabezpieczenie takiego miejsca poprzez odpowiednie oznakowanie i poinformowanie zarządcy drogi lub chociażby policji o zaistniałym zagrożeniu na drodze. Poparcie takiej tezy można wyprowadzić także z art. 25 ustawy o ochronie zwierząt, w którym odnajdujemy obowiązek prowadzącego pojazd mechaniczny, uczestniczący w wypadku z udziałem zwierzęcia, zapewnienia (w miarę możliwości) pomocy temu zwierzęciu lub powiadomienia właściwej służby. W takiej

26 Dz.U. z 2018 r. poz. 2068 z późn. zm.

27 Dz.U. z 2020 r. poz. 110 z późn. zm.

${ }^{28}$ Zgodnie $\mathrm{z}$ art. 45 komentowanej ustawy zabronione jest pozostawianie na drodze przedmiotów, które mogłyby zagrozić bezpieczeństwu ruchu; jeżeli usunięcie takich przedmiotów nie jest możliwe, należy je oznaczyć w sposób widoczny w dzień i w nocy.

29 Bezpieczeństwo i porządek na drogach publicznych wpisują się w szersze pojęcie bezpieczeństwa publicznego, ponieważ naruszenie porządku stanowi równocześnie zagrożenie dla bezpieczeństwa publicznego, traktowanego także w kategoriach bezpieczeństwa w ruchu drogowym — D. Podleś, B. Wiśniewski, [w:] Bezpieczeństwo wewnętrzne RP w ujęciu systemowym i zadań administracji publicznej, red. B. Wiśniewski, S. Zalewski, Bielsko-Biała 2006, s. 33. 
sytuacji należałoby się raczej skłaniać do powiadomienia podmiotów ${ }^{30}$ wskazanych w art. 33 ust. 3 komentowanej ustawy, szczególnie w przypadkach dzikiej zwierzyny o sporych rozmiarach. Takie działanie jest jak najbardziej uzasadnione brzmieniem odpowiednich zapisów ustawy z dnia 5 grudnia 2008 roku o zapobieganiu oraz zwalczaniu zakażeń i chorób zakaźnych u ludzi ${ }^{31}$, które w związku z art. 33 ust. 3 ustawy o ochronie zwierząt wskazują na podmioty właściwe do podjęcia odpowiednich czynności polegających między innymi na fizycznym kontakcie z rannym, a w szczególności martwym zwierzęciem.

\section{ODPOWIEDZIALNOŚĆ SKARBU PAŃSTWA}

Rozpatrując obowiązki Skarbu Państwa, reprezentowanego przez właściwe w przedmiotowym zakresie podmioty, rozważania należy sprowadzić do zwierzyny łownej ${ }^{32}$. Zgodnie z art. 5 ustawy z dnia 13 października 1995 roku Prawo łowieckie ${ }^{33}$ lista gatunków zwierząt łownych wskazana jest w rozporządzeniu Ministra Środowiska z dnia 11 marca 2005 roku w sprawie ustalenia listy gatunków zwierząt łownych ${ }^{34}$. Ustawodawca jednoznacznie podkreślił w art. 2 komentowanej ustawy, że zwierzęta łowne w stanie wolnym, jako dobro ogólnonarodowe, stanowią własnośćc ${ }^{35}$ Skarbu Państwa. Zauważyć należy, że tak sformułowany przepis prowadzi do słusznego wniosku, iż tylko zwierzęta występujące w przyrodzie w stanie wolnym nie są objęte rzeczywistym władaniem żadnego podmiotu. Potwierdzeniem tej tezy jest również konstrukcja art. 5 pkt 15a ustawy z dnia

30 Są to: lekarz weterynarii, członek Polskiego Związku Łowieckiego, inspektor organizacji społecznej, której statutowym celem działania jest ochrona zwierząt, funkcjonariusz policji, straży ochrony kolei, straży gminnej, Straży Granicznej, pracownik Służby Leśnej lub Służby Parków Narodowych, strażnik Państwowej Straży Łowieckiej, strażnik łowiecki lub strażnik Państwowej Straży Rybackiej. Podobnie w sytuacji rannego zwierzęcia, które może wymagać pomocy, przy czym jego zachowanie może być niebezpieczne dla otoczenia - R. Stec, Straże przyrodnicze $w$ Polsce i ich pozycja w systemie prawnym bezpieczeństwa i porządku publicznego. Wybrane aspekty administracyjnoprawne, Warszawa 2015, s. 160.

31 Dz.U. z 2019 r. poz. 1239 z późn. zm.

32 Z uwagi na kategorię zwierzyny i możliwości fizyczne władania tą zwierzyną czy kontrolowania jej, odpowiedzialność ma charakter obiektywny, niezależny od zamiarów podmiotu zobowiązanego - M. Goettel, Zasady wynagradzania szkód wyrządzonych przez zwierzęta wolno żyjace, „Ochrona Środowiska. Prawo i Polityka” 2002, nr 4.

33 Dz.U. z 2020 r. poz. 67 z późn. zm.

34 Dz.U. Nr 45, poz. 433 z późn. zm. W komentowanym rozporządzeniu zwierzyna łowna podzielona została na dwie grupy - zwierzynę grubą i zwierzynę drobną, przy czym dookreślono dodatkowo, które osobniki traktować należy jako zwierzynę płową, a które jako drapieżniki.

35 Obowiązki Skarbu Państwa rozpatrywane są w kontekście prawa własności obejmującego zwierzynę łowną - R. Stec, Uprawianie towiectwa i prowadzenie gospodarki łowieckiej. Uwarunkowania administracyjnoprawne, cywilnoprawne i organizacyjne, Warszawa 2012, s. 72. 
16 kwietnia 2004 roku o ochronie przyrody ${ }^{36}$, który definiuje zwierzę dziko występujące w przyrodzie jako niepochodzące $\mathrm{z}$ uprawy lub hodowli oraz wprowadzone do środowiska przyrodniczego w celu odbudowy lub zasilenia populacji.

Obowiązki Skarbu Państwa związane z usuwaniem martwej zwierzyny realizowane są zgodnie $\mathrm{z}$ art. 67 § 2 ustawy z dnia 17 listopada 1964 roku Kodeks postępowania cywilnego ${ }^{37}$ przez organ państwowej jednostki organizacyjnej, z której działalnością wiąże się realizowane zadanie ${ }^{38}$. Pomocnym w ustaleniu podmiotu bezpośrednio zobowiązanego do realizacji przedmiotowych zadań wydaje się być art. 6 ustawy Prawo łowieckie, który jednoznacznie wskazuje na ministra środowiska jako naczelny organ administracji rządowej. Dodatkowo art. 7 komentowanej ustawy obowiązki w analizowanym zakresie powierza samorządowi województwa jako podmiotowi sprawującemu administrację w zakresie łowiectwa. Można zatem stwierdzić, że zarząd województwa będzie najwłaściwszym podmiotem zobowiązanym do realizacji zadań związanych z usuwaniem martwej zwierzyny łownej należącej do Skarbu Państwa. Należy jednak zauważyć, że właściwość zarządu województwa reprezentującego Skarb Państwa w zadaniach związanych z usuwaniem martwej zwierzyny ograniczony został w swoisty sposób przez miejsce znalezienia martwego osobnika. Uzasadniony wydaje się pogląd, że w sytuacji gdy zwierzę padnie na terenach leśnych należących do Skarbu Państwa, to zgodnie z art. 4 ust. 1 ustawy z dnia 28 września 1991 roku o lasach ${ }^{39}$ podmiotem właściwym będzie Państwowe Gospodarstwo Leśne Lasy Państwowe, które prowadząc gospodarkę leśną ${ }^{40}$, sprawuje także pieczę, przejmując właściwe obowiązki, nad zwierzyną znajdującą się na jej terenie. Potwierdza to analiza definicji gospodarki leśnej zawarta w art. 6 ust. 1 pkt 1 omawianej ustawy. W świetle tego przepisu przez gospodarkę leśną rozumieć należy działalność leśną także w zakresie gospodarowania zwierzyną czy pozyskiwania — z wyjątkiem skupu — zwierzyny. W tym przypadku obowiązki Lasów Państwowych ograniczone są względem zwierzyny wyłącznie do obszarów leśnych, przy czym zauważyć należy, że nie istnieją żadne regulacje ograniczające przedmiotowe obowiązki wyłącznie do zwierzyny łownej. Uzasadniony wydaje się zatem pogląd, że podmiot ten odpowiedzialny będzie za usunięcie z terenu lasu każdej martwej zwierzyny, która padła na jego terenie. Obowiązek ten wynika niejako ze zdublowanego prawa własności - z jednej strony do obszarów leśnych będących własnością Skarbu

36 Dz.U. z 2020 r. poz. 55.

37 Dz.U. z 2019 r. poz. 1460 z późn. zm.

38 Zob. także J. Stelmasiak, Odpowiedzialność administracyjna w ochronie środowiska, [w:] Ekologia i prawo. Materiaty sesji naukowej, red. A. Przyborowska-Klimczak, Lublin 1999.

39 Dz.U. z 2020 r. poz. 6 z późn. zm.

40 Lasy poza funkcją produkcyjną pełnią także funkcję ochronną — również dla zwierząt. Należy zatem uwzględnić możliwość zapewnienia bezpieczeństwa na ich terenie wszystkim użytkownikom - W. Rakoczy, Wybrane problemy prawa leśnego, Warszawa 2011, s. 110. 
Państwa, a z drugiej strony do zwierzyny, która jest własnością Skarbu Państwa, chociażby znalazła się w jego władaniu poprzez wejście na teren lasu.

\section{ODPOWIEDZIALNOŚĆ W GRANICACH PRYWATNEJ POSESJI}

Analizując działania podmiotów administrujących w zakresie usuwania i utylizacji martwej zwierzyny, nie sposób pominąć sytuacji, w których martwe zwierzę znajduje się na terenie prywatnej posesji. Gdy mamy do czynienia ze zwierzętami domowymi czy zwierzętami gospodarskimi ${ }^{41}$, nie ma większych problemów interpretacyjnych. Natomiast gdy mamy do czynienia ze zwierzyną łowną, dziką czy bezpańską na terenach prywatnych, różne podmioty administrujące w przedmiotowym zakresie dokonują zgoła odmiennej wykładni obowiązujących przepisów. Śledząc praktykę organów administrujących, łatwo można dojść do wniosku, że zdobycze naszej kultury administrowania, polegające na poszanowaniu praw zwierząt, zapewnieniu im należytej opieki i godności, kończą się wraz z ich śmiercią. Przerzucanie się obowiązkami wynikającymi z konieczności usunięcia i utylizacji martwej zwierzyny jest na porządku dziennym. Prawo zabrania pozbywania się zwłok zwierząt na własną rękę. Niedopuszczalne jest grzebanie zwłok zwierzęcych we własnym ogródku czy w pobliskim lesie. Nie można także ich topić, spalać czy porzucać w żadnym miejscu. Postępowanie ze zwłokami zwierzęcymi ${ }^{42}$ regulują w szczególności zapisy rozporządzenia Parlamentu Europejskiego i Rady (WE) nr 1069/2009 z dnia 21 października 2009 roku określające przepisy sanitarne dotyczące produktów ubocznych pochodzenia zwierzęcego, nieprzeznaczonych do spożycia przez ludzi, i uchylającego rozporządzenie (WE) nr 1774/2002 (rozporządzenie o produktach ubocznych pochodzenia zwierzęcego $)^{43}$. Istotny nacisk położony został tutaj na stwierdzenie, że produkty uboczne pochodzenia zwierzęcego ${ }^{44}$, nieprzeznaczone do spożycia przez ludzi, stanowią

41 W kwestii zwierząt gospodarskich świadomość w zakresie obowiązku prawidłowej ich ochrony sprowadza się także do właściwego podejścia przed i w trakcie uśmiercania. Takie postrzeganie ochrony zwierząt daje podstawy sądzić, że postępowanie ze zwłokami zwierzęcia nie będzie zbytnio odbiegać od tych zasad - por. M. Gabriel-Węglowski, Przestęstwa przeciwko humanitarnej ochronie zwierząt, Toruń 2008. Takie wnioskowanie wydaje się możliwe do wyartykułowania $\mathrm{z}$ analogicznego (choć niedotyczącego uśmiercania) pojmowania ścisłego związku między życiem a zdrowiem człowieka z uwagi na to, że zdrowie jest czynnikiem w pełni determinującym życie — zob. S. Pieprzny, Ochrona bezpieczeństwa i porządku publicznego w prawie administracyjnym, Rzeszów 2007, s. 50.

${ }^{42}$ Pojęcie to zdefiniowane zostało w art. 2 pkt 26 ustawy z dnia 11 marca 2004 roku o ochronie zdrowia zwierząt oraz zwalczaniu chorób zakaźnych zwierząt (Dz.U. z 2018 r. poz. 1967 z późn. zm.) jako zwierzęta padłe lub zabite w celu innym niż spożycie przez ludzi.

43 Dz. Urz. L. 300 z 14 listopada 2009 roku, s. 1 z późn. zm.

44 Produkty uboczne pochodzenia zwierzęcego powstają przede wszystkim przy uboju zwierząt do spożycia przez ludzi, przy produkcji wyrobów pochodzenia zwierzęcego oraz przy usuwaniu 
potencjalne zagrożenie dla zdrowia ludzi i zwierząt, mogą także mieć poważny wpływ na zdrowie ludzi i zwierząt, bezpieczeństwo łańcucha żywnościowego i paszowego oraz zaufanie konsumentów. Dobitne stwierdzenie, że zagrożenia związane z martwymi zwierzętami lub ich częściami należy odpowiednio kontrolować, na przykład kierując produkty do bezpiecznych kanałów usuwania, wymusza na ustawodawcy krajowym podjęcie adekwatnych, spójnych i kompleksowych działań $\mathrm{w}$ zakresie uregulowania postępowania $\mathrm{z}$ omawianymi produktami. Znalazło to wyraz zarówno w regulacjach ustawy z dnia 20 lipca 1991 roku o Inspekcji Ochrony Środowiska ${ }^{45}$, jak i ustawie z dnia 29 stycznia 2004 roku o Inspekcji Weterynaryjnej ${ }^{46}$.

Z analizy przedstawionych powyżej regulacji prawnych wyprowadzić można jednoznaczny wniosek, że obowiązek usunięcia zwłok martwej zwierzyny obciąża właściciela zwierzęcia zarówno domowego, jak i gospodarskiego. Ustawodawca przewidział kilka sposobów wywiązania się z tego obowiązku. Najczęściej polega to na przekazaniu zwłok zwierzęcia do podmiotu zajmującego się transportem ubocznych produktów zwierzęcych ${ }^{47}$, a także przekazaniu do zakładu pośredniego, to jest zakładu gospodarki komunalnej ${ }^{48}$, który posiada uprawnienia do odbioru i czasowego składowania zwłok zwierząt. Szczegółowy zakres informacji na temat podmiotów prowadzących taką działalność określony został w rozporządzeniu Ministra Rolnictwa i Rozwoju Wsi z dnia 25 kwietnia 2018 roku w sprawie rejestru podmiotów prowadzących działalność nadzorowaną na podstawie przepisów o ochronie zdrowia zwierząt oraz zwalczaniu chorób zakaźnych zwierząt ${ }^{49}$. Mniej popularnym sposobem wywiązania się z obowiązku prawidłowego postępowania $\mathrm{z}$ martwym zwierzęciem jest skorzystanie z możliwości pozostawienia zwłok zwierzęcia w lecznicy weterynaryjnej. Wynika to przede wszystkim z faktu, że nie wszystkie lecznice dysponują odpowiednimi warunkami do zbierania i czasowego przechowywania zwłok zwierzęcych, a przede wszystkim z faktu, że związane jest to ze znacznymi kosztami. Podobnie sytuacja wygląda z możliwo-

zwierząt martwych. Przy ustalaniu zagrożenia dla zdrowia ludzi, zwierząt i środowiska nie jest istotne, w który sposób spośród z wymienionych powstają — zob. P. Kalinowski, Przepisy sanitarne dotyczace produktów ubocznych pochodzenia zwierzęcego, Lex 2019.

45 Dz.U. z 2019 r. poz. 1355 z późn. zm.

46 Dz.U. z 2018 r. poz. 1557.

47 Podmiot taki musi spełniać warunki określone dla podmiotów prowadzących działalność nadzorowaną, które zgodnie $\mathrm{z}$ art. 6 ust. 1a ustawy o ochronie zdrowia zwierząt oraz zwalczaniu chorób zakaźnych zwierząt wymagają rejestracji przez powiatowego lekarza weterynarii — szerzej: M. Rudy, Wstęp do prawa sanitarnego i weterynaryjnego, Wrocław 2010, s. 224-238.

48 Tego typu usługi świadczą także niektóre schroniska dla zwierząt, jeżeli dysponują odpowiednimi warunkami do zbierania zwierząt spoza schroniska, by następnie przekazać je do utylizacji. Szczegółowe warunki prowadzenia schronisk określone zostały w rozporządzeniu Ministra Rolnictwa i Wsi z dnia 23 czerwca 2004 roku w sprawie szczegółowych wymagań weterynaryjnych dla prowadzenia schronisk dla zwierząt (Dz.U. Nr 158, poz. 1657).

49 Dz.U. poz. 818. 
ścią umieszczenia zwierzęcia na grzebowisku ${ }^{50}$ (cmentarzu dla zwierząt). Liczba takich miejsc w Polsce nadal jest znikoma ${ }^{51}$, a ceny za taką usługę są odpowiednio wysokie.

\section{ZAKOŃCZENIE}

Człowiek występujący w przyrodzie na szczycie drabiny ewolucyjnej został postawiony w roli dominującej nad wszystkimi organizmami na ziemi ${ }^{52}$. Podejście do ochrony zwierząt i postępowanie ze zwierzętami po ich śmierci wynika nie tylko z ograniczonej liczebności gatunków dziko występujących w przyrodzie, uznania prawa zwierząt do godnego bytowania ${ }^{53}$, ale także ze świadomości człowieka powiązanej z jego dominującą pozycją w przyrodzie i odpowiedzialnością za świat zwierząt, który sobie podporządkował. To człowiek definiuje zakres ochrony zwierząt, który związany jest z ludzkimi postawami, implikowanymi miejscem i czasem ochrony oraz w pewnym stopniu odrębnościami kulturowymi.

Przez analizę wybranych przypadków wykazano, że obowiązek utrzymania czystości i porządku ciąży na właścicielu nieruchomości, drogi, lasu, również w zakresie dotyczącym obowiązku usunięcia zwłok martwej zwierzyny. W gąszczu podmiotów administrujących w zakresie postępowania z martwą zwierzyną wskazać należy także na te, które, w świetle skomentowanej ustawy o zapobieganiu i zwalczaniu zakażeń i chorób zakaźnych u ludzi, zobowiązane są do usuwania z prywatnych nieruchomości padłych zwierząt, a ustawa ta stanowi lex specialis w stosunku do ustawy o utrzymaniu czystości i porządku w gminach.

Trudności interpretacyjne powstają w sytuacji, kiedy zaczynamy rozważać zwłoki jako odpad, w takiej bowiem sytuacji trudno jest ustalić wytwórcę odpadu, szczególnie gdy chodzi o zwierzęta dziko występujące w przyrodzie i to

50 Rada gminy określa w drodze uchwały wymagania, jakim powinien podołać przedsiębiorca prowadzący działalność kontrolowaną w takim zakresie - P. Ćwiek, Zezwolenie na prowadzenie schronisk dla bezdomnych zwierzą, grzebowisk i spalarni zwłok zwierzęcych i ich części, Lex 2019. Por. M. Sandej, Cmentarz dla zwierząt nie może być za górami i lasami, Lex 2018.

$51 \mathrm{~W}$ całej Polsce liczba cmentarzy dla zwierząt towarzyszących znajdujących się pod nadzorem Inspekcji Weterynaryjnej określona została na 14 - zob. www.wetgiw.gov.pl/handel-eksport-import/utylizacja-podmioty-nadzorowane-przez-inspekcje-weterynaryjna (dostęp: 2.01.2020).

52 „Niech panuje nad rybami morskimi, nad ptactwem powietrznym, nad bydłem, nad ziemią i nad wszystkimi zwierzętami pełzającymi po ziemi” — werset z Księgi Rodzaju (1:26), Pismo Święte Starego i Nowego Testamentu. Biblia Tysiąclecia, red. A. Jankowski, Poznań-Warszawa 1971, s. 22 i 23.

53 Z uwzględnieniem dobrostanu zwierzęcia pojmowanym jako zapewnienie komfortu fizycznego i psychicznego. To człowiek odpowiedzialny jest za definiowanie i określanie cierpienia zwierzęcia za życia - H. Mamzer, Czy jest możliwy uwspólniony dobrostan ludzi i innych zwierząt, [w:] Dobrostan zwierząt. Różne perspektywy, red. H. Mamzer, Gdańsk 2018, s. 30. Odpowiedzialność ta nie kończy się z chwilą śmierci zwierzęcia, ponieważ martwe zwierzę nie przestaje oddziaływać na świat ludzi i zwierząt ani na wszystkie elementy przyrody. 
bez względu na miejsce, w którym się znajdują. W sytuacji, kiedy analizujemy kategorię zwierząt domowych i gospodarskich, odpad w postaci zwłok martwej zwierzyny jest nierozłącznie związany z działalnością człowieka (właściciela zwierzęcia). W tym wypadku raczej nie ma wątpliwości, na kim ciąży obowiązek usunięcia martwej zwierzyny. Z kolei w sytuacji, gdy mamy do czynienia ze zwierzyną łowną czy bezpańską, analiza obowiązujących regulacji w przedmiotowym zakresie nie pozwala jednoznacznie wskazać podstawy prawnej obowiązku usunięcia martwej zwierzyny z terenu prywatnej nieruchomości. Zwierzęta łowne, które znalazły się na prywatnym terenie, nie stają się automatycznie własnością właściciela nieruchomości. Tym samym zwłoki martwej zwierzyny łownej powinny być traktowane jako odpad nierozłącznie związany z działalnością Skarbu Państwa, który jako właściciel zwierzyny łownej wydaje się najwłaściwszym podmiotem do zrealizowania obowiązku i poniesienia związanych z tym kosztów usunięcia i utylizacji martwej zwierzyny. Nie można wszak traktować zwierzyny łownej jako zwierzyny bezpańskiej, w sytuacji gdy znajdzie się na prywatnym terenie czy na terenach przynależnych do gminy. Podobne wnioskowanie wydaje się właściwe, jeżeli chodzi o zwierzynę uznaną za bezdomną, która znalazła się na prywatnym terenie. Tutaj oczywiście dużo zależy od woli właściciela nieruchomości, który może przygarnąć takie zwierzę, ale jeśli taka wola nie zostanie wyrażona, zwierzę uznawane za bezdomne nie staje się automatycznie własnością osoby tylko przez sam fakt wejścia na jej teren.

Można zatem wyrazić pogląd, że obowiązek uprzątnięcia zwłok zwierzyny winien być rozpatrywany $\mathrm{w}$ kontekście podmiotu, któremu przysługuje prawo własności zwierzyny, a dopiero w drugiej kolejności podmiotu zobowiązanego do utrzymania czystości.

\section{LIABILITY OF ADMINISTRATIVE ENTITIES FOR DEAD ANIMALS}

\section{Summary}

The study indicates administrative entities which are competent in the scope of removing dead animals, with particular emphasis on activities related to stray animals and wild animals. The article includes provisions regarding the procedure itself and the systemic position of the competent authorities, as well as their tasks and competences at the administrative and legal level. The paper analyses particularly significant problems in the light of the provisions regulating the ownership rights of movable property and in relation to events occurring in private property. Moreover, it includes the case analysis related to the obligation to remove dead wild animals from private property.

Keywords: animal protection, dead animals, maintaining order and cleanliness, utilisation of animal corpses 


\section{BIBLIOGRAFIA}

Bartkowski T., Ksztaltowanie i ochrona środowiska, Warszawa 1979.

Boć J., O bezpieczeństwie wewnętrznym, [w:] Bezpieczeństwo wewnętrzne w działaniach terenowej administracji publicznej, red. A. Chajbowicz, T. Kocowski, Wrocław 2009.

Boć J., Nowacki K., Samborska-Boć E., Ochrona środowiska, Wrocław 2008.

Ćwiek P., Zezwolenie na prowadzenie schronisk dla bezdomnych zwierząt, grzebowisk i spalarni zwłok zwierzęcych i ich części, Lex 2019.

Gabriel-Węglowski M., Przestępstwa przeciwko humanitarnej ochronie zwierząt, Toruń 2008.

Gałkowski J., Zasada proporcjonalności, „Więź” 1983, z. 1.

Goettel M., Zasady wynagradzania szkód wyrządzonych przez zwierzęta wolno żyjące, „Ochrona Środowiska. Prawo i Polityka" 2002, nr 4.

Górski M., Prawo ochrony środowiska, Warszawa 2009.

Górski M., Miłkowska-Rębowska J., Komentarz do art. 13 Traktatu o funkcjonowaniu Unii Europejskiej, [w:] Traktat o funkcjonowaniu Unii Europejskiej. Komentarz, t. I (art. 1-89), red. D. Miąsik et al., Lex 2012.

Janik C., Status zwierzęcia w głównych systemach religijnych, [w:] Status zwierzęcia. Zagadnienia filozoficzne i prawne, red. T. Gardocka, A. Gruszczyńska, Torun 2012.

Jendrośka J., Modele samorządu terytorialnego, [w:] Prawo administracyjne, red. J. Boć, Wrocław 2010.

Kaleta T., Zwierzęta we wspótczesnych religiach światowych. Wybrane zagadnienia, „Życie Weterynaryjne" 2011, nr 86 (9).

Kalinowski P., Przepisy sanitarne dotyczące produktów ubocznych pochodzenia zwierzęcego, Lex 2019.

Maciejko W., Zaborniak P., Ustawa o drogach publicznych. Komentarz, Warszawa 2010.

Mamzer H., Czy jest możliwy uwspólniony dobrostan ludzi i innych zwierząt, [w:] Dobrostan zwierząt. Różne perspektywy, red. H. Mamzer, Gdańsk 2018.

Mitera M., Kilka uwag o prawach zwierząt, [w:] Przełomy wieków, red. M. Szyszkowska, Białystok 2000.

Nowacki K., W Austrii, [w:] Gmina w Europie Zachodniej, red. J. Jeżewski, Wrocław 1995.

Pieprzny S., Ochrona bezpieczeństwa i porzadku publicznego w prawie administracyjnym, Rzeszów 2007.

Pismo Święte Starego i Nowego Testamentu. Biblia Tysiąclecia, red. A. Jankowski, Poznań-Warszawa 1971, s. 22 i 23.

Podleś D., Winiewski B., [w:] Bezpieczeństwo wewnętrzne RP w ujęciu systemowym i zadań administracji publicznej, red. B. Wiśniewski, S. Zalewski, Bielsko-Biała 2006.

Probucka D., Filozoficzne podstawy idei praw zwierząt, Kraków 2013.

Radecki W., Utrzymanie czystości i porzadku w gminach. Komentarz, Warszawa 2012.

Rakoczy B., Prawo ochrony przyrody, Warszawa 2009.

Rakoczy W., Wybrane problemy prawa leśnego, Warszawa 2011.

Rudy M., Wstęp do prawa sanitarnego i weterynaryjnego, Wrocław 2010.

Rychter R., Ustawa o drogach publicznych. Komentarz, wyd. 2, Lex 2019.

Rydzicki Z., Sybiga J., Utrzymanie porzadku i czystości w gminach, Warszawa 1997.

Sandej M., Cmentarz dla zwierząt nie może być za górami i lasami, Lex 2018.

Stec R., Straże przyrodnicze w Polsce i ich pozycja w systemie prawnym bezpieczeństwa i porządku publicznego. Wybrane aspekty administracyjnoprawne, Warszawa 2015.

Stec R., Uprawianie towiectwa i prowadzenie gospodarki łowieckiej. Uwarunkowania administracyjnoprawne, cywilnoprawne i organizacyjne, Warszawa 2012.

Stelmasiak J., Odpowiedzialność administracyjna w ochronie środowiska, [w:] Ekologia i prawo. Materiaty sesji naukowej, red. A. Przyborowska-Klimczak, Lublin 1999. 
Węgrzynowicz R., Romańska M., Ochrona zwierząt w świetle prawa i norm etycznych, [w:] Prawna ochrona zwierząt, red. M. Mozgawa, Lublin 2002.

Zadania $i$ kompetencje jednostek samorzadu terytorialnego $i$ wojewody, red. Z. Bukowski et al., Torun 2004.

Przegląd Prawa i Administracji CXX, 2020, cz. 1 i 2

(C) for this edition by CNS 